\title{
Sexual and Gender Diversity in Clinical Practice in Psychology ${ }^{1}$
}

\author{
Icaro Bonamigo Gaspodini², Denise Falcke ${ }^{2}$ \\ ${ }^{2}$ Universidade do Vale do Rio dos Sinos, São Leopoldo-RS, Brazil
}

\begin{abstract}
Clinical psychologists should foster the health promotion for people affected by prejudice and discrimination. This study aimed to investigate how issues of sexual and gender diversity appear and are experienced by professionals of clinical practice in Psychology. Participants in this qualitative and exploratory study were 14 female psychologists (aged between 24 and 60 years old) living in five cities of the state of Rio Grande do Sul, in Brazil. Three focus groups were performed and the dialogues were submitted to thematic analysis. It was noted that clinical practices of depathologization were motivated by: belief in a psychosocial nature about diversity, concern with stereotypes and inadequate language, clinical training via knowledge based on depathologization and interpersonal contact with LGBT people. On the other hand, pathological practices are motivated by: belief in a biological, psychological, religious or ethical-moral nature about diversity, non-observance of stereotypes and inappropriate language reproduction, clinical training via pathological knowledge (explicit and implicit), silencing, and none or little interpersonal contact with LGBT people.
\end{abstract}

Keywords: prejudice, psychologist's training, psychologist's performance, therapist's attitudes, clinical psychology

\section{Diversidade Sexual e de Gênero na Prática Clínica em Psicologia}

Resumo: Psicólogos(as) clínicos(as) devem oportunizar promoção de saúde para pessoas atingidas por preconceito e discriminação. Este estudo teve por objetivo investigar como questões de diversidade sexual e de gênero aparecem e são vivenciadas por profissionais da prática clínica em Psicologia. Participaram deste estudo qualitativo e exploratório 14 psicólogas (24 a 60 anos) residentes em cinco cidades do Rio Grande do Sul. Três grupos focais foram realizados e os diálogos transcritos foram submetidos à análise temática. Observou-se que práticas clínicas despatologizantes são motivadas por: crença em uma natureza psicossocial sobre a diversidade, preocupação com estereótipos e linguagem inadequada, formação clínica via conhecimentos despatologizantes e contato interpessoal com pessoas LGBT. Por outro lado, práticas patologizantes são motivadas por: crença em uma natureza biológica, psicológica, religiosa ou ético-moral sobre a diversidade, inobservância da reprodução de estereótipos e linguagem inadequada, formação clínica via conhecimentos patologizantes (explícitos e implícitos), silenciamentos e nenhum ou pouco contato interpessoal com pessoas LGBT.

Palavras-chave: preconceito, formação do psicólogo, atuação do psicólogo, atitudes do terapeuta, psicologia clínica

\section{Diversidad Sexual y de Género en la Práctica Clínica en Psicología}

Resumen: Los psicólogos(as) clínicos(as) deben fomentar la promoción de la salud para las personas afectadas por prejuicio y discriminación. Este estudio tuvo como objetivo el estudio de cómo las cuestiones de diversidad sexual y de género aparecen y son experimentadas por profesionales de la práctica clínica en Psicología. Participaron de este estudio cualitativo y exploratorio 14 psicólogas (de 24 a 60 años) residentes en cinco ciudades del estado de Rio Grande do Sul, Brasil. Tres grupos focales se realizaron y los diálogos transcritos se sometieron al análisis temático. Se observó que las prácticas clínicas despatologizantes están motivadas por: creencia en una naturaleza psicosocial sobre la diversidad, preocupación por estereotipos y lenguaje inadecuado, formación clínica vía conocimientos despatologizantes y contacto interpersonal con personas LGBT. Por otro lado, las prácticas patologizantes son motivadas por: creencia en una naturaleza biológica, psicológica, religiosa o ético-moral sobre la diversidad, inobservancia de la reproducción de estereotipos y lenguaje inadecuado, formación clínica vía conocimientos patologizantes (explícitos e implícitos), silenciamientos y ninguno o poco contacto interpersonal con personas LGBT.

Palabras clave: prejuicio, formación del psicólogo, actuación del psicólogo, actitudes del terapeuta, psicología clínica

\footnotetext{
'Paper derived from the master's dissertation of the first author under the supervision of the second, defended in 2017, in the Graduate Program in Psychology of the Universidade do Vale do Rio dos Sinos. Support: Coordination for the Improvement of Higher Education Personnel (CAPES). Correspondence address: Icaro Bonamigo Gaspodini. Universidade do Vale do Rio dos Sinos. Programa de Pós-Graduação em Psicologia. Av. Unisinos, 950, Bairro Cristo Rei, São Leopoldo-RS, Brazil. CEP 93.020-190. E-mail: icaroicaro@gmail.com
}

Clinical practices in Psychology play an important role in promoting health and preventing violence against lesbian, gay, bisexual, transvestite and transgender (LGBT) people. LGBT people access more mental health services compared to heterosexual and cisgender people (that is, non-transgender) (Cochran, Sullivan, \& Mays, 2003). However, these people 
are more dissatisfied with health services when compared to the general population, largely due to the discriminatory attitudes of the professionals and teams themselves (Palma \& Stanley, 2002).

In Brazil, LGBT users of the public health system identified the presence of homophobic discourses related to HIV and treatments based on heterosexual sexuality, disregarding issues of gender and sexual identity (Cerqueira-Santos et al., 2010). This information points to the need for training of health professionals in relation to sexual and gender diversity (Carvalho \& Philippi, 2013). For this purpose, with regard to Psychology, it is necessary to review the assumptions that organize psychological understandings of diversity, since historically Psychology has reproduced notions of normality and abnormality in relation to sexuality (Jesus, 2013). Medical manuals such as the Diagnostic and Statistical Manual of Mental Disorders (DSM) and the International Statistical Classification of Diseases and Related Health Problems (ICD) have helped to construct a pathological knowledge about LGBT persons, implying disease character to sexual orientations and identities or expressions of gender different from the majority (Bento \& Pelúcio, 2012; Conselho Federal de Psicologia [CFP], 2011). The fact that such manuals subsidize a large part of the clinical practice in Psychology justifies this concern.

Although homosexuality has been removed from the classification of mental disorders in the second version of the DSM (American Psychiatric Association, 1973), gender diagnoses continue to be reclassified to every edition of the manual, such as "transsexualism", "gender identity disorder" or "gender dysphoria" as it appears in the latest version (American Psychiatric Association, 2013). The same is true of the ICD. The term "homosexuality" was taken from the tenth version in 1990 (Organização Mundial da Saúde [OMS], 1997), while the term "transsexualism" appears in the ninth version of the manual (OMS, 1975) and is maintained in ICD-10, in which "bivalent transvestism" and "gender identity disorders" are also included. Currently, a modification of the next version is discussed, which will use the nomenclature "gender incongruity", likely to be published in 2018 (Beeket al., 2016). This brief history presents pathological knowledge about sexual and gender diversity that have been and are present in the clinical practices in Psychology. For this reason, the constant training on the subject is necessary to offer an adequate service to the LGBT public, mainly regarding the observance of discriminatory attitudes.

There are few available studies on training of psychologists to work with issues of sexual and gender diversity. Models of interventions for the development of clinical competence in the psychological care of the LGBT public have recently appeared in the United States. The training of multicultural skills, for example, suggested by Hope and Chappell (2015), extends the focus on racial or ethnic issues, originally presented by
Sue, Arredondo and McDavis (1992). According to Hope and Chappell (2015), the following guidelines provide the basis for implementation and evaluation of these programs: (1) identification of main competencies in the dimensions of beliefs and attitudes, knowledge, skills, and action; (2) integration of multicultural skills training in official curricula; (3) taking action to attract LGBT students and teachers; (4) choosing or creating places of professional practice that include sexual minorities; (5) development of competence in research respecting multicultural competencies; (6) choice of multicultural competency assessment strategies that include the LGBT issue. In addition, gender issues (for example, transvestites and transsexuals) should be included in these programs, as they are generally focused on non-heterosexual sexual orientation - for example, homosexuals and bisexuals (Cochran \& Robohm, 2015).

Interventions aimed at reducing prejudices that include the cognitive, affective and behavioral components are more successful when compared to purely educational interventions (Bartoş, Berger, \& Hegarty, 2014). In this sense, Costa et al. (2016) recently presented evidence of effectiveness of an online multidimensional intervention on the reduction of prejudice against sexual and gender diversity with health professionals. The need to work on the role of professionals' personal beliefs and attitudes beyond the education of theoretical aspects was evidenced, which corroborates the proposal of Bartoș et al. (2014).

In Brazil, in addition to Resolution 01/99, which prohibits the offer of treatments to modify sexual orientations (CFP, 1999), some efforts are undertaken by the Council System regarding the work with the depathologization of sexual orientations and identities or expressions of gender (CFP, 2011, n.d.; Conselho Regional de Psicologia de São Paulo, 2011; Conselho Regional de Psicologia do Rio Grande do Sul, 2016). Still, psychologists in the country have recently been surprised by an injunction suspending Resolution 01/99 and allowing the provision of a treatment called "sexual reorientation". Even if the injunction is reversed, endorsing such a practice empowers groups in favor of it.

Therefore, the relevance of Clinical Psychology in the prevention of violence and health promotion of the LGBT population is perceived, however, there is a shortage of literature on the preparation and training of psychologists on the subject. Thus, this study aimed to investigate how issues of sexual diversity and gender appear and are experienced by professionals of clinical practice in Psychology.

\section{Method}

\section{Participants}

To participate, it was necessary to be a psychologist, to be in professional action at the time of the research and to have some experience with clinical practice in 
Psychology. 182 e-mail invitations were sent to clinical psychologists in Rio Grande do Sul and about 100 e-mails to psychology clinics and related institutions. In addition, invitations were transmitted on social networks. After the dates and suggested locations for the focus groups were informed, the 14 interested psychologists were selected. The professionals resided in five cities of the state, their ages varied between 24 and 60 years and the time of profession varied between 1 and 33 years. All participants were white women, none identified as transgender, and only one identified as a lesbian. The preponderant area of action was Clinical Psychology, being that, with the exception of one, all performed or had performed clinical practices in private practices. Regarding the theoretical perspectives, the following were chosen by participants as the basis for their work: Systemic Psychology $(n=6)$, Cognitive-Behavioral Psychology $(n=3)$, Social Psychology $(n=2)$, Psychoanalysis $(n=2)$, and Humanistic Psychoanalysis $(n=1)$.

\section{Instruments}

Focus groups were used with the objective of knowing and deepening perceptions around a theme based on the interactions of a group of people, through a guide of topics related to the guiding questions (Barbour, 2009). We opted for an initial presentation of five minutes followed by four questions. The presentation showed results of the first author's master's research, which indicated that the beliefs about diversity that were most associated with prejudice are those that attribute causality to the perversion of normal behavior, poor resolution of conflicts with parental figures, and sexual abuse suffered in childhood. The questions were: (1) "What do you think about what was shown?"; (2) "How do these questions appear in your clinical practice?"; (3) "How do you perceive the role of formal preparation in issues about sexual and gender diversity?"; (4) "How can unprepared psychologists on the subject be harmful to the health of the LGBT population?". Question 4 was conditioned on the answers to the previous question, that is, it would only be done if participants identified "unprepared" in question 3.

\section{Procedure}

Data collection. After contacting the participants who accepted the invitation, dates and locations were set for three focus groups in three regions of the state. One was held in the capital on August 1, $2016(n=4)$, another in a city of the metropolitan region on August 11, $2016(n=5)$ and another in the state's interior on September 1, $2016(n=5)$. The number of participants in each focus group adhered to the minimum suggested by Barbour (2009) of four people. The composition of the groups was not intended to provide a comparison between them but to allow the expression of different points of view.

The first author coordinated the groups of the capital and metropolitan region and the second author coordinated the group held in the interior. There was an observer in the metropolitan group and an observer in the interior group. In each group, the interactions lasted on average $1 \mathrm{~h}$ and $30 \mathrm{~min}$ and were recorded in audio. Initially, the Free and Informed Consent Form was presented, which was discussed and explained before being signed. They were informed of the benefits of participating in collaboration with scientific progress and the opportunity to express opinions, as well as the risks of eventual discomfort with any individual. A psychologist collaborator was available to welcome participants who eventually gave up because of discomfort, which did not happen.

Data analysis. The dialogues were fully transcribed and submitted to thematic analysis, according to the guidelines proposed by Braun and Clarke (2006). The thematic analysis allows us to investigate experiences and meanings based on the participants' reality, and can be used as a method to reflect the reality of the data and also to reveal non-superficial meanings (Braun \& Clarke, 2006). We opted for the data approach driven by the analytical and theoretical interest of the researchers and searched latent themes corresponding to the guiding question, to the detriment of semantic themes. The six steps suggested by Braun and Clarke (2006) were followed. Initially, there was a rapprochement of the data in the transcription of the audios and in the reading of the check. Next, the initial codes corresponding to the text excerpts were generated, which were organized and grouped to form provisional themes and sub-themes. We then reviewed excerpts corresponding to the codes and refined themes and sub-themes, elaborating a thematic map. Finally, the themes were defined, named and allied to illustrative excerpts.

\section{Ethical Considerations}

The guidelines and norms for research involving human beings of the National Health Council were met, in accordance with Resolution 466, of December 12, 2012. This study was approved by the Research Ethics Committee of the Universidade do Vale do Rio dos Sinos, through Opinion No. 1,362,701.

\section{Results and Discussion}

The thematic map constructed from the analysis of the transcriptions was presented in Figure 1. The themes were represented by circles and subtopics by rectangles. The arrows suggest that the interrelationship between the beliefs and attitudes of the psychologist and their formation imply in the clinical practices that he / she performs. The thematic map was discussed using speech excerpts and / or dialogues from the focus groups. These excerpts represent recurrent themes and sub-themes between the groups, which triggered more interactions. 


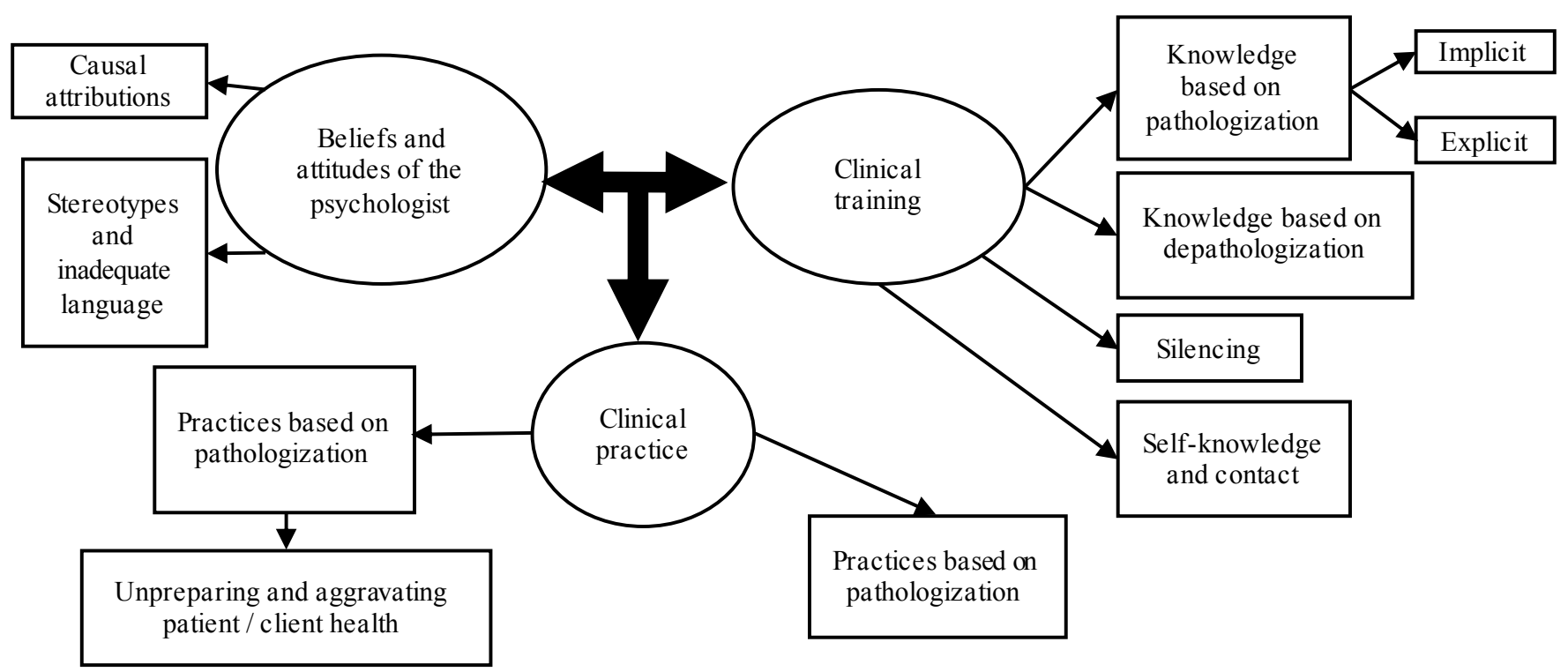

Figure 1. Thematic map of the study with 03 themes and 11 subtopics.

On the first theme, Psychologist beliefs and attitudes, assessing what psychologists think about sexual and gender diversity becomes relevant through the observation that individuals react to minority social groups according to explanatory models about these groups (Lacerda, Pereira, $\&$ Camino, 2002). Favorable or unfavorable behavioral responses would be conditioned to these representations (Herek \& McLemore, 2013; Pereira, Monteiro, \& Camino, 2009). According to Pescosolido and Martin (2015), in the processes of stigmatization, stereotypes and labels are used to devalue social identities. For the authors, discrimination is reinforcing stereotypes through behaviors such as inadequate language. This can be observed in groups, for example, when someone referred to transvestites using male pronouns or when referring to homosexuality with the term "homosexualism" (term related to pathologies).

Some psychologists have reflected on causal attributions related to sexual and gender diversity. Regarding a possible biological cause, they expressed concern about the effects of this explanation, as the excerpt shows: "But. . . there is an issue, let's think more futuristic. .., I'll choose my son's DNA. . . So I can choose whether he's going to be homosexual or not, being a bit more controversial". In this sense, people who believe that LGBT individuals are that way due to a psychosocial nature, that is, a cultural issue, tend to manifest less prejudice than those that attribute causality to a religious, ethical-moral, psychological or biological nature (Lacerda et al., 2002). The participants also reflected on the question of whether or not to be a choice, according to the following dialogue:

P1- I think there is a choice, but there is still something else, what. . . I don't know, it's complicated. . . there are the cases that are discovered later.
P2 - I think this person who says he/she found out later is that he/she resisted a lot because he/ she had to hold on. . . many family issues, many society issues, that he/she could not think of.

It has been noted that the causal attributions associated with prejudice are those that allow, in some way, the change. If the nature of diversity is religious, ethical-moral, psychological or biological, one can think of change. On the other hand, belief in a psychosocial (cultural) nature does not even require a causal explanation, as it positions all expressions of sexuality and gender as human manifestations. That was the belief manifested by most of the study's psychologists, although some have agreed to biological explanations. They also criticized traditional explanations of psychology, such as poor resolution with parental figures or perversion. There was a consensus in the perception of the negative consequences of explanations that allow change, among them, the actions of "reversion" or "repair" of sexual orientation, a practice considered inhumane, dangerous and, in the worst cases, iatrogenic (American Psychological Association, 2009; Cochran \& Robohm, 2015).

Some stereotypes were identified in the participants' speeches. It is common, for example, that people associate transvestite with prostitution, as one of the participants: "Now, my city has transvestite in the street. . . For some reason they are there. They stay temporarily and leave, but anyway, what's up? Certainly, men who seek this and do not want to leave their family". Other stereotypes manifested by psychologists referred to the association of femininity with delicacy and of homosexuality with promiscuity. The latter can be illustrated by the following dialog:

P1 - It's a world that, I think. . that they cannot create bonds, true bonds. There is a love, but I do not know if this is what you see. 
P2 - . . If you go for a heterosexual nightclub, it's exactly the same thing.

P1 - I agree, but I saw a lot more in those people.

P2 - I do not see this 'more'. I see that it is less subtle, less hidden, because there is less shame.

In this dialogue, it is possible that the presence of the single declared lesbian participant was essential in raising the issue of privilege. It is more difficult to perceive prejudice and discrimination when it benefits from the social legitimacy derived from the visibility of some social marker (Gaspodini, Canabarro, Cenci, \& Perrone, 2017). In this case, non-LGBT psychologists could neglect the prejudice suffered in the same way as white psychologists on the issue of racial prejudice. If the perception of one's privileges can improve the perception of the other's suffering (Gaspodini et al., 2017), this has direct application in clinical practices in Psychology.

As for the second main topic, Clinical training of the psychologist, we identified types of learning that are present during graduation and post-graduation, in addition to courses and technical training. From the dialogues of the groups, it was understood that the knowledge about sexual and gender diversity can be experienced in four ways: (1) explicit and implicit pathological knowledge, (2) knowledge based on depathologization, (3) silencing and (4) self-knowledge and contact.

An explicit pathological knowledge alludes to theories and techniques that reproduce models of sexuality centered on the supremacy of the heterosexual-cisgender individual. They are notions and constructs that disregard diversity as a human manifestation and take it as a deviation or disorder. An illustrative piece of this kind of knowledge may be the following: "I learned in psychopathology the question of gender dysphoria and now gender incongruity, but no one has ever taught me 'this one is heterosexual, let's learn about him?', 'when did he find out that he is heterosexual?'”. From the psychoanalytic as well as the psychiatric tradition, one has inherited, for example, the notion of perversion, as found by one participant: "It was what we learned at that time, that being homosexual was a perversion. And that kind of approach there is totally perverse". Other notions mentioned in the groups referred to poor resolution of conflicts with parental figures and sexual abuse suffered in childhood. These three notions are taken by many as factors that would lead the individual to not be heterosexual (Lacerda et al., 2002). In this sense, Ceccarelli (2010) raises the possibility that diagnostic manuals, together with interests of the pharmaceutical industry, classify personal experiences in pathologies, transforming the singular into abnormal.

It was precisely the pathologization, that is, the attribution of the disease character to the non-socially accepted expressions of sexuality (Bento \& Pelúcio, 2012), which allowed the offer of treatments of conversion or, more recently, "sexual reorientation". In fact, until the end of the twentieth century, heterosexual behavior was maintained as a model of sexuality, allowing the offer of these treatments (Jesus, 2013), which included the use of electroshock and hormonal therapies (Daniel \& Baudry, 1977). Today, the consensus among the international scientific community is that these practices mean serious threats to the mental health, well-being and life of the individuals involved (OMS, 2012).

An implicit pathological knowledge can be transmitted through jokes, ironic comments, stereotyped examples of human behavior or any attitude that promotes pathologization: "Although they did not treat it as perversion. . . teachers indirectly said yes, it was perversion. In the speech of. . ., you felt almost explicitly saying this: 'It's a serious problem that has treatment"'. This type of learning was also observed in expressions of fear or discomfort to discuss or research subjects related to the theme during the lessons, according to the excerpt: "My interest was to do my Final Paper with "trans" people,. . . but none of my teachers encouraged me". In fact, in contemporary times, due to the proliferation of social norms that aim to combat prejudice, it began to take on more veiled, subtle or camouflaged forms (Pettigrew \& Meertens, 1995, 2001). It is not, however, a "lesser" expression of violence, since such attitudes are used to justify discriminatory acts.

In this sense, it is pointed out to the need of the positioning of teachers as one of the elements proposed by Hope and Chappell (2015), in their model of training of psychologists. The authors suggest that actions be taken to attract not only students but also teachers who are part of the LGBT community. This has a fundamental impact on the formation of future psychologists, given the students' contact with the activism of professionals who stand against the violation of human rights.

On the other hand, a knowledge based on depathologization comprises all sexual orientations and gender identities or expressions as manifestations of human diversity, not as psychopathological manifestations (American Psychological Association, 2009; CFP, 2011). The following excerpt illustrates this point: "When I studied psychodiagnosis. . . they brought up another idea of what we had seen at graduation, not as illness, but as you having various manifestations. It seemed to be such an obvious explanation, but it lacked clarity". In the focal group of the capital, the psychologists with the longest experience reminded of the controversy caused by the depathologization movements in the academic environment: "Among the students, it was very welcome (Resolution 01/99 of the CFP - Portuguese acronym for Federal Council of Psychology), since they were younger, but by the teachers, who already had all the training, the discussion was long. They were still clinging to that belief'.

Although homosexuality has been removed from the manuals of mental disorders, transgenderity presents a different history in these catalogs. That is why, since 2012, an international campaign called Stop Trans Pathologization has been struggling to remove gender diagnoses from DSM and from ICD. In addition to this claim, it is intended to remove the 
mention of "gender" from official documents and registries, eliminate normalizing treatments for intersex people and guarantee free access, independent of psychiatric guardianship, to hormonal treatments and surgeries for "trans" people (Bento \& Pelúcio, 2012). In order to convey an effectively knowledge based on depathologization, it is suggested that educational activities be based on the perspective that includes gender and sexuality as social, historical and political processes (Costa, Peroni, Camargo, Pasley, \& Nardi, 2015). The knowledge based on depathologization is also reflected in the openness to the debate in the classroom and in the support for students to research the subject by other paradigms different from the traditional ones.

Another type of knowledge identified in this study, the silencing, can be understood as a form of knowledge made invisible. In the dialogues of the groups, it was noticed that the LGBT issue is commonly silenced due to unpreparedness, discomfort, fear or lack of support from teachers to discuss or research on this subject. All participants agreed that there was little or no instruction to this effect in their training. The activities they witnessed were not based on official curricula but on events organized by interested individuals. This corroborates what had been verified by Borges, Canuto, Oliveira and Vaz (2013), that approaches on the subject, in the training in Psychology, depend mainly on initiatives of students and teachers that are moved by the theme of some form.

Finally, a last type of knowledge identified among those with whom in-formation psychologists come into contact refers to self-knowledge and contact. The investigation of the prejudices themselves and the search for knowledge based on depathologization, although not officially available in the curricula, were suggestions of the participants for this task. In addition, it has been suggested that psychologists meet and approach LGBT people, which in the literature is known as interpersonal contact (Cerqueira-Santos, Winter, Salles, Longo, \& Teodoro, 2007). Interpersonal contact is associated with lower levels of prejudice (Cerqueira Santos et al., 2007; Costa et al., 2015), because the negative representations attributed to minority social groups are reduced through the personal experience of contact, friendship, labor relations, among others (Cerqueira-Santos et al., 2007). Therefore, selfknowledge and interpersonal contact become a fundamental part of the psychologist's preparation (American Psychological Association, 2009; Hope \& Chappell, 2015). The following dialogue represents the need for self-knowledge and contact:

P1 - We, after graduating, are in the office and the patient brings these questions and we are quiet, we have to be able to listen. . .

P2 - But there is a student who does not know how to handle and is amazed.

P3 - But it is precisely this, it has to be worked out, the student's prejudices at the time of attendance.
So far, it has been the first two main themes resulting from the analysis, which, through their interrelation, impact on the third theme identified: clinical practice. It is within this scope that one can observe the result of the combination of beliefs and personal attitudes with the clinical training experienced during graduation or postgraduate studies. The theme "clinical practice" indicated three related subtopics: pathological practices, practices based on depathologization and unpreparedness and aggravations to the health of patients / clients.

The clinical practices of the psychologist will be based on his / her technique, acquired, maintained and perfected by the training, as well as on his / her personal characteristics. The relationship between training and personal beliefs about sexual and gender diversity implies how the practitioner conducts his / her practices. In this study, psychologists reported knowing pathological practices, such as offering "cure" of homosexuality, especially of psychologists related to religious contexts, but not restricted to these people: "We have found business cards of religious psychologists in pubs" (GF - Capital). On the other hand, the following dialogue indicates a change in the service to the LGBT public:

P1 - As if you had to transform the person, to convince that person to be.

P2 - Cure!

P1 - Cure! ... Not today, when the person comes for treatment, this is not on the agenda, except for some things of family acceptance, but this relates to the relationships of how they deal, but not in that sense as if it were a disease.

Treatments that were and still are offered for individuals to modify their sexual orientation mean serious threats to mental health, well-being and life (OMS, 2012) and their consequences include depression, anxiety and suicidal tendency (American Psychological Association, 2009). The psychologists of this study condemned such treatments; however, it was possible to identify pathological practices in some speeches. With regard to trans people, for example, it was assumed that the decision to have a surgery should be conditioned to the opinion of a professional, mainly because of the possible regret: "Imagine if you give a clinical report. . . and then the person regrets. It's a very complicated situation". This was considered a suicidogenous view by Bento and Pelúcio (2012), in which "trans" people are viewed a priori as potentially suicidal, through the rhetoric of victimization. This is related to another indicator of pathological practices that has to do with assuming an a priori suffering in the LGBT patient / client motivated by his /her sexual orientation and gender identity or expression issues. However, one cannot deny the high rates of suicide among "trans" people and the 
suffering imposed on them by a social-normative and cissexist structure. However, it is strongly suggested that the professional who assumes that the suffering presented by the individual necessarily concerns with the fact that the person belongs to the LGBT community.

On the other hand, practices based on depathologization were identified in the groups, for example, policing their own discriminatory attitudes, self-criticism and constant improvement, as well as preparation and humanization of public or private clinical spaces. Simple attitudes could help to prevent the reproduction of prejudice, for example: "Today I try to police myself, because it is prejudice. Why does a man come and you ask, 'Do you have a wife?' 'You may not have a wife, you can have a husband". Some psychologists have suggested working together on the power relationship involved in the demand for surgeries for transgender people. The decision on hormonal and surgical procedures should be made by the individual and not by the psychologist. This is in accordance with the technical note issued by the Regional Council of Psychology of Rio Grande do Sul (2016), which opposed the construction of a report and suggests the elaboration of a psychological opinion based on the guidelines announced, which agree with the international depathologization movement. This opinion must be carried out together with the person who requires it, focusing on the suffering caused by the difficulty of accessing basic individual rights. In addition, self-esteem in LGBT patients / clients has also emerged in the groups: "I came across person's own difficulty in accepting his / herself". It is self-stigma, which manifests itself in the LGBT people themselves when they accept the legitimacy of social stigma and direct against themselves the negative status of these representations (Herek \& McLemore, 2013).

Finally, it was noticed, in the statements of the participants, indications of unpreparedness of the professional, as well as possible aggravations to the health of patients / clients. The majority expressed their own difficulties, according to one participant: "I was very scared to deal with this, for not knowing how to treat, for not knowing the denominations of what is trans, what is this or that ... People take time to know what this is, I took some time". In all groups it was mentioned the lack of preparation regarding the specificities of the health demands of the LGBT population. An example of this involves "trans" people: "A specific complaint of wanting to change sex. What do we do in these cases? I really do not know, if it gets to me, I do not know what to do". Forms of health hazard found in this study involve neglect and referral due to unpreparedness, reproduction of discriminatory attitudes and stereotypes, non-confrontation of explicit or implicit violence and, as previously mentioned, the consequences of nefarious processes that promise to change sexual orientations and gender identities or expressions. A possible situation of being experienced by psychologists involves adults requesting treatments related to the sexuality of children. At this point, the professional should be prepared to reflect on such demand with the adult himself. One participant experienced an experience of unpreparedness in this sense:
We had an internship experience with a family and I noticed the difficulty. . to look at this and say to that father: 'Look, there is no cure, what you are asking is impossible because it is not a disease'.

It can be concluded, therefore, that professionals who perform clinical practices based on depathologization are probably motivated by the following factors: (1) belief in a psychosocial (cultural) nature about diversity; (2) concern about the reproduction of stereotypes and inappropriate language; (3) clinical training that contains knowledge based on depathologization, self-knowledge and interpersonal contact with LGBT people. Such professionals will probably attend their patients / clients from the perspective that the individual's suffering is not related to being or not LGBT, but associated with the social pressures of cultures that stigmatize their sexuality or gender expression.

On the other hand, what is commonly observed are the reasons why the clinical psychologist will resort to pathological practices. This is likely to be motivated by: (1) belief in a biological, psychological, religious or ethicalmoral nature about diversity; (2) disregard for stereotypes and inappropriate language reproduction; (3) clinical training via pathological knowledge (explicit and implicit), silencing and no or little interpersonal contact with LGBT people. These are the professionals who are likely to attend to the individual based on suffering aprioristically caused by being LGBT. It is possible that, keeping the heterosexual-gender model, they disregard the specificities of the individuals' experiences and find it more difficult to perceive the suffering of the other. The offer of treatments and interventions may aim to normalize the individual from a single model of sexuality and gender.

This study aimed to investigate how psychologists experience sexual and gender diversity issues in their clinical practice in Psychology. Professional characteristics such as beliefs and attitudes as well as their training imply in the way you perform their clinical practices. Regarding the personal characteristics, the main beliefs about sexual and gender diversity and the reproduction of some stereotypes and inadequate language were identified. It was understood that, during training, the psychologist may come into contact with diverse forms of knowledge about diversity, being they based on pathologization or depathologization forms. These forms of knowledge are related to the type of clinical practice performed, with pathological knowledge and silencing being responsible for possible health problems for LGBT people.

Among the limitations identified in the study, it can be pointed out that the content of the focus groups was analyzed as a whole, not exploring in depth the possible comparisons between them. In addition, the fact that the participants have an interest in the subject and also seek to guide their practices in knowledge based on depathologization may have minimized the expression of beliefs and attitudes that would probably be manifested in other groups with other professionals. It is also necessary to take into account the context of social desirability in relation to their opinions on the subject, considering 
the general guidelines available to professionals of Psychology regarding the issue of prejudice.

Based on this work, it is pointed out that the lack of knowledge based on depathologization about sexual and gender diversity produced by Psychology itself, due to the pathological character of the medical-psychiatric knowledge that has historically been produced. It is suggested that the next studies proceed from the exploratory delineation of the present study to comparative, correlational or explanatory results, mainly to investigate the relationship between the types of learning experienced by the psychologist in the training and the clinical practices resulting from this learning mediated or not by their personal beliefs. Emphasis is given to the need to address these issues in the official Psychology curricula, through the dissemination of quality scientific studies and the constant training planning for students and professionals of Psychology on sexual and gender diversity, with a view to respecting the whole the diversity of people seeking psychological help.

\section{References}

American Psychiatric Association. (1973). Homosexuality and sexuality orientation disturbance: Proposed change in DSM-II. Arlington, VA: Author.

American Psychiatric Association. (2013). Diagnostic and statistical manual of mental disorders (5th ed.). Washington, DC: Author.

American Psychological Association.(2009). Report of the APA task force on gender identity and gender variance. Retrieved from https://www.apa.org/pi/lgbt/resources/ policy/gender-identity-report.pdf

Barbour, R. (2009). Grupo focais [Focal groups]. (M. F. Duarte, Trad.). (Coleção Pesquisa Qualitativa). Porto Alegre, RS: Artmed.

Bartoş, S. E., Berger, I., \& Hegarty, P. (2014). Interventions to reduce sexual prejudice: A study-space analysis and meta-analytic review. The Journal of Sex Research, 51(4), 363-382. doi:10.1080/00224499.2013.871625

Beek, T. F., Cohen-Kettenis, P. T., Bouman, W. P., Vries, A. L. C., Steensma, T. D., Witcomb, G. L., ... Kreukels, B. P. C. (2016). Gender incongruence of adolescence and adulthood: Acceptability and clinical utility of the World Health Organization's proposed ICD-11 criteria. PLOS ONE, 11(10). doi:10.1371/journal.pone.0160066

Bento, B., \& Pelúcio, L. (2012). Despatologização do gênero: A politização das identidades abjetas [Depathologization of the gender: The politicization of abject identities]. Revista Estudos Feministas, 20(2), 559-568. doi:10.1590/s0104-026x2012000200017

Borges, L. S., Canuto, A. de A. A., Oliveira, D. P. de, \& Vaz, R. P. (2013). Abordagens de gênero e sexualidade na Psicologia: Revendo conceitos, repensando práticas [Approaches to gender and sexuality in Psychology: Reviewing concepts, reviewing practices]. Psicologia: Ciência e Profissão, 33(3), 730-745. doi:10.1590/s1414-98932013000300016
Braun, V., \& Clarke, V. (2006). Using thematic analysis in psychology. Qualitative Research in Psychology, 3(2), 77-101. doi:10.1191/1478088706qp063oa

Carvalho, L. S., \& Philippi, M. M. (2013). Percepção de lésbicas, gays e bissexuais em relação aos serviços de saúde [Lesbian, gay and bissexuals' perception of health services]. Universitas: Ciências da Saúde, 11(2), 83-92. doi:10.5102/ucs.v11i2.1837

Ceccarelli, P. R. (2010). A nova ordem repressiva [The new repressive order]. Psicologia: Ciência e Profissão, 30(4), 738-751. doi:10.1590/S1414-98932010000400006.

Cerqueira-Santos, E.,Calvetti, P. U., Rocha, K. B., Moura, A., Barbosa, L. H., \& Hermel, J. (2010). Percepção de usuários gays, lésbicas, bissexuais e transgêneros, transexuais e travestis do Sistema Único de Saúde [LGBT people perceptions of Brazilian public health care system]. Interamerican Journal of Psychology, 44(2), 235-245. http://www.redalyc.org/ articulo.oa? $\mathrm{id}=28420641004$

Cerqueira-Santos, E.,Winter, F. D. S., Salles, L. A., Longo, J. L., \& Teodoro, M. (2007). Contato interpessoal e crenças sobre homossexualidade: Desenvolvimento de uma escala[Interpersonal contact and beliefs about homosexuality: Scale development]. Interação em Psicologia, 11(2), 221-229. doi:10.5380/psi.v11i2.6639

Cochran, B., \& Robohm, J. S. (2015). Integrating LGBT competencies into the multicultural curriculum of graduate psychology training programs: Expounding and expanding upon Hope and Chappell's choice points. ClinicalPsychology: ScienceandPractice, 22(2), 119-126. doi:10.1111/cpsp.12099

Cochran, S. D., Sullivan, J. G., \& Mays, V. M. (2003). Prevalence of mental disorders, psychological distress, and mental services use among lesbian, gay, and bisexual adults in the United States. Journal of Consulting and Clinical Psychology, 71(1), 53-61. doi:10.1037/0022-006X.71.1.53

Conselho Federal de Psicologia. (1999). Resolução $N^{o}$ 001/99, de 22 de março de 1999 [Resolution No 001/99, from March 22, 1999]. Brasília, DF: Autor.

Conselho Federal de Psicologia. (2011). Psicologia e diversidade sexual: Desafios para uma sociedade de direitos [Psychologyand sexual diversity: Challenges for asocietyofrights]. Brasília, DF: Autor.

Conselho Federal de Psicologia. (n.d.). Despatologização das identidades trans e travestis [Depathologization of trans and transvestite identities]. Retrieved from http://despatologizacao.cfp.org.br

Conselho Regional de Psicologia de São Paulo. (2011). Psicologia e diversidade sexual: Caderno temático 11 [Psychology and sexual diversity: Thematic issue 11]. São Paulo, SP: Autor. 
Conselho Regional de Psicologia do Rio Grande do Sul. (2016). Nota Técnica do CRPRS acerca da produção de documentos psicológicos em situações de alteração/adequação de nome no registro civil e de procedimentos de modificação corporal de pessoas transexuais e travestis [CRPRS's technical note on psychological documents necessary for name change and corporal modifications for transexuals and transvestites]. Retrieved from http:/www.crprs.org.br/upload/others/ file/6c19186c57ef302582397d32f69db5f4.pdf

Costa, A. B., Pase, P. F., Camargo, E. S. de, Guaranha, C., Caetano, A. H., Kveller, D., ... Nardi, H. C. (2016). Effectiveness of a multidimensional web-based intervention program to change Brazilian health practitioners' attitudes toward the lesbian, gay, bisexual and transgender population. Journal of Health Psychology, 21(3), 356-368. doi:10.1177/1359105316628748

Costa, A. B., Peroni, R. O., Camargo, E. S. de, Pasley, A., \& Nardi, H. C. (2015). Prejudice toward gender and sexual diversity in a Brazilian public university: Prevalence, awareness, and the effects of education. Sexuality Research and Social Policy.doi:10.1007/s13178-015-0191-z

Daniel, M., \& Baudry, A. (1977). Os homossexuais [The homosexuals]. Rio de Janeiro, RJ: Artenova.

Gaspodini, I. B., Canabarro, R. P., Cenci, C. M. B., \& Perrone, C. M. (2017). Masculinidades em diálogo: Produção de sentido a partir de marcadores sociais da diferença [Masculinities in dialogue: Sense production from social markers of difference]. Mudanças: Psicologia da Saúde, 25(1), 17-25. doi:10.15603/2176-1019/mud.v25n1p17-25

Herek, G. M., \& McLemore, K. A. (2013). Sexual prejudice. Annual Review of Psychology, 64, 309-333. doi:10.1146/annurev-psych-113011-143826

Hope, D. A., \& Chappell, C. L. (2015). Extending training in multicultural competencies to include individuals identifying as lesbian, gay, and bisexual: Key choice points for clinical psychology training programs. Clinical Psychology: Science and Practice, 22(2), 105-118. doi:10.1111/cpsp.12099

Jesus, J. G. de. (2013). O conceito de heterocentrismo: Um conjunto de crenças enviesadas e sua permanência [The concept of heterocentrism: A set of biased beliefs nd its permanence]. Psico-USF, 18(3), 363-372. doi:10.1590/s1413-82712013000300003

Lacerda, M., Pereira, C., \& Camino, L. (2002). Um estudo sobre as formas de preconceito contra homossexuais na perspectiva das representações sociais [A study of prejudice forms against homosexuals anchored on social representations]. Psicologia: Reflexão e Crítica, 15(1), 165-178. doi:10.1590/s0102-79722002000100018

Organização Mundial da Saúde. (1975). Classificação internacional de doenças: Adaptada para uso em processamento de dados [International classification of diseases: Adapted for usage in data processing]. Porto Alegre, RS: Sagra.
Organização Mundial da Saúde. (1997). Classificação estatística internacional de doenças e problemas relacionados à saúde (10a rev.) international statistical classification of diseases and related health problems]. São Paulo, SP: Universidade de São Paulo.

Organização Mundial da Saúde. (2012). “Therapies” to change sexual orientation lack medical justification and threaten health. Retrieved from http://www.paho.org

Palma, T. V., \& Stanley, J. L. (2002). Effective counseling with lesbian, gay and bisexual clients. Journal of College Counseling, 5(1), 74-89. doi:10.1002/j.2161-1882.2002.tb00208.x

Pereira, A. S. L. S., Monteiro, M. B., \& Camino, L. (2009). Estudo da validação das escalas de crenças sobre a natureza da homossexualidade e de preconceito contra homossexuais [Validation study on scales of beliefs about nature of homosexuality and prejudice against homosexuals]. Laboratório de Psicologia, 7(1). doi:10.14417/lp.683

Pescosolido, B. A., \& Martin, J. K. (2015). The stigma complex. Annual Review of Sociology, 41, 87-116. doi:10.1146/annurev-soc-071312-145702

Pettigrew, T. F., \& Meertens, R. W. (1995). Subtle and blatant prejudice in Western Europe. European Journal of Social Psychology, 25(1), 57-75. doi:10.1002/ejsp.2420250106

Pettigrew, T. F., \& Meertens, R. W. (2001). In defense of the subtle prejudice concept: A retort. European Journal of Social Psychology, 31(3), 299-309. doi:10.1002/ejsp.45

Sue, D. W., Arredondo, P., \& McDavis, R. J. (1992). Multicultural counseling competencies and standards: A call to the profession. Journal of Multicultural Counseling and Development, 20(2), 64-88. doi:10.1002/j.2161-1912.1992.tb00563.x

Icaro Bonamigo Gaspodini is a Ph.D. candidate of the Universidade do Vale do Rio dos Sinos, São Leopoldo-RS, Brazil.

Denise Falcke is a Professor of the Universidade do Vale do Rio dos Sinos, São Leopoldo-RS, Brazil.

Received: Feb. 03, 2017

1st Revision: Oct. 27, 2017

2nd Revision: Jan. 06, 2018

Approved: Feb. 20, 2018

How to cite this article:

Gaspodini, I. B., \& Falcke, D. (2018). Sexual and gender diversity in clinical practice in psychology. Paidéia (RibeirãoPreto), 28, e2827. doi:http://dx.doi.org/10.1590/1982-74327e2827 